ISSN 2338-4778 (Print) ISSN 2548-4192 (Online)

\title{
Observing the Intellectual Curiosity of English Education Students in the Class
}

\author{
Arny Irhani Asmin \\ arny.as@uncp.ac.id \\ Computer Engineering, Universitas Cokroaminoto Palopo, Indonesia
}

Received: 19 March 2020 Accepted: 9 May 2020

DOI: $10.24256 /$ ideas.v8i1.1263

\begin{abstract}
Intellectual curiosity also known as epistemic curiosity, it is one of the important abilities that determines student's creativity and motivation. There are three main components of epistemic responses is observed in this study, they are observations, thinking and consultations. Through classroom observations and interview, the researcher found out that students need to be encouraged and trained continuously to improve their intellectual curiosity in the class. Data showed that almost all students were not focused on paying attention to the teacher explanations, lack of ideas, rarely ask or respond the questions and not actively participating in group or class discussion. Overall, the students were passive in developing creative ideas and showing lack of motivation to learn in class. Thus, teachers are strongly advised to encourage students' intellectual curiosity in learning process because curiosity allows students to think creatively, critically, and boost their academic performance.
\end{abstract}

Keywords: Intellectual curiosity, epistemic curiosity, English students

\section{Introduction}

The quality of education often associated with the teachers. The teacher is the main focus of the critics of the irregularity of the education system, but on the other hand the teacher is also the figure most expected to reform the education level. The teacher becomes the most important link that connects teaching with hopes for a better education future. However, the quality of Indonesian education has not met its optimal point. The central factor that spearheads education quality 
is the teacher. The best teachers will make the quality of education more advanced. If education has advanced, then the capacity of this nation will continue towards the forefront. So that no more and no less, teachers become one of the important pillars in the advancement of civilization through education. Thus, to produce professional and qualified teachers, it must start from the beginning when the teacher still in college as teacher training student.

In the era of the industrial revolution 4.0 , the capacity of teachers should have been up to version 4.0, and even better if it had reached 5.0. Many education experts agree that one of the 5.0 teacher capacities that prospective teachers should have Intellectual Curiosity. In Cambridge English dictionary, curiosity means an eager wish to know or learn about something, it is a desire to learn and know something. Curiosity is the expression of desire to learn and get knowledge. It expands the mind and opens it to variant opinions and topics. According to Kashdan (2007) "curiosity is a pleasant motivational state involving the tendency to recognize and seek out novel and challenging information and experiences". In other word, intellectual curiosity means the ability to think creatively.

In teaching and learning process at schools in Indonesia, students tend to be passive in communication, very few of them ask questions in class. This phenomenon generally happens in the classroom from the secondary level up to college. This issue has attracted the interest of some researchers such as Cholifah, Hendri \& Deswati (2013), Widodo (2012), Khairunisa (2017), Sriyati, Rukmana and Wahyu (2019), all of them have researched about students' questioning skills. They agreed that asking questions is closely related to intellectual curiosity, because by asking students shows their interest and curiosity. Moreover, Rustaman (2005) has written that asking is one types of skills students must have. A curious student will ask questions, read and explore, they also tend to think critically as Ennis (2011) has said that to one of sun-indicators of critical thinking skills is asking question. Mitchell (2015) writes that "curiosity is a hidden force that drives learning, critical thinking, and reasoning. Moreover, Mitchell added that it can be recognized when we observed children exploring their environment, devouring books and information, asking questions, investigating concepts, manipulating data, searching for meaning, connecting with people and nature, and seeking new learning experiences."

Curiosity encourages students to question everything and dig deeper. Therefore, teachers are in the perfect position to act as the whetstone to help students to realize their potential. Thus, one of the capacities that a great teacher should have in the future is closely correlated with curiosity. Thus, intellectual 
curiosity is an essensial elements of the process of learning especially for the prospective teacher students who will become the future teachers.

This study of intellectual curiosity took place in the University of Cokroaminoto in Palopo, South Sulawesi. For years, the researcher has taught in various classes and level as lecturer in faculty of Education and Teacher Training, the researcher always questioning about student's curiosity in learning. Even though various methods and strategies in teaching had been tried but the students seem less interested in learning, asking questions or expressing opinion during learning process. On the top of that, this kind of case occurred in all classes.

The centre goal of this study is to figure out the students' intellectual curiosity in the classroom. It is important to investigate this issue because these students are the candidate teachers who are expected to bring changes in the quality of education in Indonesia.

\section{Intellectual Curiosity}

In 1960, Berlyne presented a specific theory of curiosity in his book entitled: Conflict, Arousal, and Curiosity. His conceptualization of curiosity has been widely accepted. The term "curiosity" in Colling dictionary means a desire to know about something. "Curiosity can be defined as the "urge to know more" that manifests behaviourally in questioning and exploration" (Clerk, 2017). According to Lindholm (2018), "Curiosity is a wonder of the human mind. It goes to the heart of modernity as a driving force for leaning, novel insights, and innovation both individual and communities". Moura Koutoujian, a career and life coach writes in the Jody Michael Associates (2018) that "Curiosity involves finding the unfamiliar in the familiar. She says "Curiosity is not defined by if you are paying attention, but rather by how you are paying attention." Moreover, Graham \& Helen (2011) argue that "Curiosity is an aspect of intrinsic motivation that has great potential to enhance student learning". In addition, von Stumm, Hell \& Chamorro-Premuzic (2011) states that "Curiosity is basically a hunger for exploration". They say "If you're intellectually curious, you'll go home, you'll read the books. If you're perceptually curious, you might go traveling to foreign countries and try different foods." Both of these, they thought, could help you do better in school. Curiosity ignites innovations, creativity and expanded personal relationship and other social benefit because the hunger of mind the more it can be digest.

According to Berlyne in Olson (1986), there are many different types of curiosity, some of them are Adjustive-reactive curiosity, Conceptual curiosity, Curiosity about the complex or ambiguous, Diversive curiosity, Epistemic curiosity, 
Manipulatory curiosity, Perceptual curiosity, Reactive curiosity, Specific curiosity, State curiosity, Trait curiosity (Olson, 1986). This study focused on Epistemic Curiosity or Intellectual Curiosity. Epistemic Curiosity refers to "responses through which knowledge is acquired." There are three main classes of epistemic responses, and they are:

a. Observation, which includes responses which place the subject in contact with external situations and which nourish the learning process;

b. Thinking, which includes productive or creative thinking and which puts the individual in permanent possession of new knowledge; and

c. Consultation, which exposes an individual to verbal stimuli from others and includes asking questions, writing letters, and reading (Berlyne in Olson, 1986).

Intellectual curiosity describes the desire to learn and understand more about people, cultures, ideas and concepts. Being a curious is important because you ask questions, learn from others and look for ways to do better. Intellectual curiosity is vital for keeping our mind sharp and agile. "Someone who curious has motivation and invest time to and energy into search of knowledge (Ram, 2016)." If students show more interest in what teacher doing and saying in the classroom, it indicates that they care and want to learn and progress.

There are many reasons to embrace intellectual curiosity in the classroom such as; to encourage meaningful dialogue or discussion between teacher to students or student to student; to promote mindfulness, curiosity linked to mindfulness because mindfulness allows students to observe, while curiosity helps students explore. Intellectual curiosity can also increase collaboration in the classroom, a sense of curiosity allows students to consider situation from another person's perspective, and to collectively inspired innovation. Furthermore, student who has intellectual curiosity have an inquisitive mindset which helps them to understand others (Michael, 2018).

Thus, teachers should encourage students' intellectual curiosity in learning process because curiosity allows students to think creatively and critically, and boost their academic performance especially for the students major in education, because they will be the future teachers which will determine the quality of education in the future.

Intellectual Curiosity and Future Teacher

Future teacher is the education students who learn in college and chose the major of education. Students are learnt to develop skills and knowledge to teach others as a teacher in the future. In Indonesia, the quality of teachers relatively 
lower compared to other countries like Malaysia and Singapore. Teacher quality need to be improved and upgraded both knowledge and teaching skills. Ko (2003) believe that teacher quality is a general term for teacher cultivation process professional qualification and abilities. Therefore, Horn \& Sanders, Wright (1997) concluded that teacher quality should cover; professional competence, personality, teacher-student interaction, student problem handling, and performance responsibility. The researcher personally believed that most of the qualities above can be achieve if the teachers have intellectual curiosity. To identify student's curiosity, teacher can observe from the student activeness in asking questions and giving opinions.

Curiosity is associated with intellectual and a teacher should be the intellectual one. However, be an intellectual teacher is not an instant process, it is a lifelong learning. Teacher needs long-term practice, reflections and comprehensive expression of teacher's capacity (Tian, 2007). Therefore, to make the teacher students get all the qualities of a good teacher, lecturers in education school have to train and encourage student's enthusiasm to be more curious in the classroom.

Curiosity is linked with academic achievement and deeper learning of student. It is a vital aspect of academic performance. Schmitt and Lahroodi (2008) say that stimulating curiosity is central to education and learning because it is essential for inquiry and knowledge. Many researchers found that curiosity influence academic performance. Curiosity closely linked to intelligence and intelligence is important to academic performance. Von Stumm, Hell \& Chamorro-Premuzic (2011) say that

"Teachers have a great opportunity to inspire curiosity in their students, to make them engaged and independent learners. That is very important", They also explains that curious person has the greatest potential for development. As what Albert Einstein, one of the smartest men in history said "I have no special talents. I am only passionately curious."

\section{Method}

Through this qualitative research, the experiences of the subjects examined in their real contexts, that was in the classroom setting.

Subject: the subjects in this study are limited to the English Education students of the University of Cokroaminoto Palopo (the sixth semester students).

Instruments: In collecting data, the researcher applied participant observation by using field notes observations and unstructured interview was applied to get 
details and students confirmations of observations data.

Data Collection: In collecting primary data, the researcher conducted observations in the classroom. The researcher conducted the observations in her own class. Researcher observed the student's intellectual curiosity based on Berlyne's theory on epistemic curiosity class responses included observation, thinking and consultation. Participant observations implemented for six meetings. While unstructured interview as supporting data is given to clarify what was happen during classroom meetings. Data is collected by involving 27 students at the sixth semester at English Language Education Department.

Procedure: Procedure in collecting data from observations were done in a natural setting. Subjects were free from any control. Learning and teaching process proceed as usual for six meetings. Subjects were taught by using various methods such as Total Physical Response, Think Pair Share, Interactive Guessing Games, Case Study \& Group Discussion. After observations, the researcher conducted interview to confirm issues found in observations. Observations and interview were based on the Berlyne's theory on epistemic (intellectual) curiosity class responses included observation, thinking and consultation.

Analysis of Data: Data is analysed inductively by following these steps;

a. Organized the data, data from observation notes is collected, and data from interview are arranged, transcribe and label the data and then retrieved appropriated data.

b. Identified framework, exploratory framework is applied to identify the needed data. The researcher read again the data to label and define the data needed.

c. Sorted data in framework, after data is identified, the researcher sorted it and modified the framework.

d. Use the framework data for descriptive analysis, the last step was describing the data in detail and answer the research questions.

\section{Results}


The goal of the present research was to figure out the students' intellectual curiosity in the classroom. Data were collected through observations and interview. Observations and interview were based on the Berlyne's theory on epistemic (intellectual) curiosity class responses included observation, thinking and consultation.

To figure out the students' intellectual curiosity in the classroom, observations were conducted for six meetings and in a natural setting. As guided in observations, the researcher elaborated Berlyne's components into several item statements. The following table shows the indicators and items statements which observed in the classroom.

Table 1. Observation Guide

\begin{tabular}{|c|c|c|}
\hline Observation & \multirow{2}{*}{$\begin{array}{l}\text { Thinking } \\
\text { a.Remember the point of } \\
\text { teacher's explanation }\end{array}$} & \multirow{2}{*}{$\begin{array}{l}\text { Consultation } \\
\text { a.Ask questions before } \\
\text { teacher asks }\end{array}$} \\
\hline $\begin{array}{l}\text { a. Focus on the } \\
\text { explanation }\end{array}$ & & \\
\hline b. Not paying attention & b. Analyse the information & $\begin{array}{l}\text { b. Ask questions after } \\
\text { teacher asks }\end{array}$ \\
\hline $\begin{array}{l}\text { c. Increase attention } \\
\text { during explanation }\end{array}$ & $\begin{array}{l}\text { c. Creatively } \\
\text { information }\end{array}$ & $\begin{array}{l}\text { c. Ask questions if teacher } \\
\text { gives reward }\end{array}$ \\
\hline d. Take some notes & $\begin{array}{l}\text { d. Imaginative/ thinking } \\
\text { new ideas }\end{array}$ & $\begin{array}{l}\text { d. No one asking } \\
\text { questions }\end{array}$ \\
\hline $\begin{array}{l}\text { e. Actively participating in } \\
\text { class activities }\end{array}$ & e.Exploring new idea & $\begin{array}{l}\text { e.Ask new things \& } \\
\text { experiences }\end{array}$ \\
\hline $\begin{array}{l}\text { f. Showing learning } \\
\text { interest }\end{array}$ & $\begin{array}{l}\text { f. Think about contradicting } \\
\text { idea }\end{array}$ & $\begin{array}{l}\text { f. Ask for further } \\
\text { explanation }\end{array}$ \\
\hline $\begin{array}{l}\text { g. Try to seek as much } \\
\text { information }\end{array}$ & $\begin{array}{l}\text { g.Think about what might } \\
\text { happen }\end{array}$ & g.Ask for confirmation \\
\hline & $\begin{array}{l}\text { h. Discovering new } \\
\text { solutions }\end{array}$ & \\
\hline & i. Actively in giving answer & \\
\hline & j. Give lots of questions & \\
\hline & k. Asking "How or Why" & \\
\hline
\end{tabular}

At the beginning of class activities, when teacher explained the lesson majority of students gave attention to the teacher's explanations. Unfortunately, only some of them increased attention during explanation and showed learning interest. 
These students were the ones who have good academic performances in all classes.

The following was the description of what happened in the class.

"Teacher explained the lesson and all students sat quietly and pay attention. Some of them wrote and took notes during explanations. Then, teacher asked question to all students "Have you ever been to a foreign country" and student RP and DM gave a response "No, Ma'am, I never". And then, teacher asked the class again "What country would you like to visit and Why?", again only student RP and DM gave a response. Teacher tried to make other students talked "How about you NY?", and she said "South Korea", teacher asked "Why" but NY just smiled. Then, DM replied "because she loves K-pop Ma'am".

After class ends, the researcher asked NY “Why didn't you explain your reason for liking South Korea?" and h she replied "Eee... actually Ma'am, I want to talk but it was difficult for me to find the correct vocabulary and I was shame if my friends laugh at me", and then I asked her to explain her reason in Indonesian language and she said "Karena saya suka K-Pop $\quad$ Bu dan saya ingin ke Korea untuk melihat idola saya" in English "Because I love K-Pop Ma'am and I want to go to Korea to meet my idol".

Other things that caught the researcher's attention was the habits of students to take picture of the teacher's Power Point slides rather than taking notes in notebook. Most of them did not write down the points of teacher's explanations and tend to forget what the teacher has explained. As the result, when teacher reconfirmed the explanation, students cannot explain it at all. They did not remember teacher' explanations even though it explained twice.

The researcher asked these students why did they love to take picture of the slides rather than write it in notebook, they said "I will write it in my book at home Ma'am". And then, after a week I saw their notebook and could not find the last week's material that they said want to write it at home. It seems like they have low learning interest both at home and classroom.

The next teaching strategy applied in the class was discussion. In class and group discussion activities, students are trained to think creatively and critically. 
The researcher observed that most of them were difficult to analyse the information, thinking new ideas, and offered a solution. Student who tried to solve the problem given was the group chairman or the spokesperson of the group. In group discussion, students are divided into five groups with five students for each group. Teacher implemented Case Study teaching strategy and gave one different case that has to be solved by each group.

The following was the description of what happened in group discussion.

"Students read and studied the case; the chairman leaded the members to give opinion. One of the members started talking but stopped before her opinion was understood by other members. The chairman said "What do you mean GL, can you explain it more?" and GL repeated her opinion but sounded doubtful. "How about you NA?" the chairman looked for another opinion, and NA responded "I don't know, just write down what GL has said". Other members said "Yes, just write it like that". The chairman replied "Yes, but we need more reasons why do we offer this as the solution?" and IS said "Let's try searching it on Google?".

When every groups explained the case and the solutions, only RP, DM, SA, NS and NB who actively gave responses. Most of the students just listened, and some of them even checked their social media. Besides that, no one offered contradicting ideas at all. Overall, group and class discussion not successful in making most of students active in speaking and thinking.

Related to the third components of Berlyne that was consultation, the researcher found that only two or three students who actively proposed questions. However, they only asked after teacher said to ask questions or when teacher promised to give reward to those who ask and answer questions. DM and RP sometimes asked for further explanation and confirmation. However, for six meetings they never asked questions with 'How or Why', they tend to asked by saying "What..." and asked for confirmation by saying "So....".

Corresponding to the fact found in observations, the researcher came to the conclusion that the students' intellectual curiosity needs to be improved and 
teachers in the classroom have to train students on and on to ignite their curiosity continuously. By considering that they are the future teachers, they should have high intellectual curiosity. We hope that these students realize the importance of being curious intellectually as a lifelong learner.

The goal of this study is to figure out the students' intellectual curiosity in the classroom. There were three components of intellectual curiosity as the base theory of researcher in conducting observations, they are observation, thinking and consultation.

The results indicated that students' intellectual curiosity needs to be trained and improved. There were several issues need to be discussed, the first was there were only two students (RP and DM) who always raise hand and answer the questions. These two were them who have good academic performance in all classes. This finding was in line with what Von Stumm, Hell \& Chamorro-Premuzic (2011) said that "intellectual curiosity or 'hungry mind' was a core determinant of individual difference in academic achievement". The finding also showed that from 27 students in this class only 2 of them who can be said to have intellectual curiosity because they were actively observing, thinking and asking during class hours. As Koutoujian, says in the Jody Michael Associates (2018) that "Curiosity is not defined by if you are paying attention, but rather by how you are paying attention", these 27 students seemed gave attention during teacher's explanation but when teacher asked to confirmed their knowledge, they just kept quiet. However, the researcher understands that it was possible that the student's passive in speaking because their limited English skill considering this was English language class.

Further interesting finding to discuss related to observation of students in the class was the habits of taking picture of the teacher's note on whiteboard or Power Point slides. The researcher think that this method was not effective to remember the lesson since they did not learn it at home. Therefore, taking notes on teacher's 
explanation was better because it forces students to pay attention, focus in class and help them learn.

The next things were the fact that most of students were difficult to analyse the information, thinking new ideas, and offered a solution. These things could be seen during group discussion where only the chairman who was active in sharing ideas. In other words, the students have a lack of critical thinking skills. As Forte (2019) says "to be critical thinker, students require curiosity; It requires students to want to know more, hear more and think more". Moreover, curiosity ignites innovations, creativity and expanded personal relationship and other social benefit because the hunger of mind the more it can be digest. Graham \& Helen (2011) argue that "Curiosity is an aspect of intrinsic motivation that has great potential to enhance student learning". Thus, teacher need to ignite the student's curiosity in the class continuously, as Schmitt and Lahroodi (2008) said that stimulating curiosity is central to education and learning because it is essential for inquiry and knowledge. Furthermore, Von Stumm, Hell \& Chamorro-Premuzic (2011) say that "Teachers have a great opportunity to inspire curiosity in their students, to make them engaged and independent learners".

Due to the lack of available data, the result cannot confirm the level of students' intellectual curiosity and because the small size of subjects, these results cannot be generalized. However, the results should be taken into account when considering how to teach and train students to be more critical and creative in thinking or to ignite their intellectual curiosity. Moreover, further research is needed to find more information about students' intellectual curiosity.

\section{Conclusion}

Intellectual curiosity is vital for keeping our mind sharp and agile. As Ram (2016) says "Someone who curious has motivation and invest time to and energy into search of knowledge". Thus, it is important to teach and train our students to ignite their curiosity, in this case intellectual curiosity in classroom. To our 
knowledge, these results can be a window for us to see and aware about the importance of being curious, not only for students but also for teachers. As Einstein said "The important thing is not to stop questioning, curiosity has its reason for existence".

\section{References}

Ayşegul, Ogr \& Takkaç Tulgar, Aysegul. (2018). The effects of curiosity on second language learning in terms of linguistic. Journal of Social-Cultural and Pragmatic Development, pp. 59-72.

Budiharto, R., \& Amalia, L. Motivation behind Indonesian Undergraduates Learning English as a Target Language. IDEAS: Journal on English Language Teaching and Learning, Linguistics and Literature doi:https://doi.org/10.24256/ideas.v7i1.714.

Clark,S. (2017). Cultivating classroom curiosity: a quasi-experimental, longitudinal study investigating the impact of the question formulation technique on adolescents intellectual curiosity. (Unpublished Doctoral Dissertation) Boston University.

Chin, C. \& Osborne, J. (2008). Students' question: a potential resource for teaching and learning sciences. Studies in Science Education. 44(1). Pp. 1-39

Cholifah, S., Hendri, W., \& Deswati, L. (2013). Analisis faktor-faktor penyebab kesulitan siswa dalam mengungkapkan pertanyaan pada proses pembelajaran biologi kelas VII SMP Bunda Padang. E-Journal Universitas Bung Hatta. 2 (4), pp. $11 . \quad$ Retrieved from http://ejurnal.bunghatta.ac.id/index.php?journal=JFKIP

Elizabeth, E., \& Ena, O. (2019). Intrinsic and Extrinsic Motivation of English Education Graduation Students Batch 2018 in Accomplishing Academic Performance. IDEAS: Journal on English Language Teaching and Learning, Linguistics and Literature, 7(2). doi:https://doi.org/10.24256/ideas.v7i2.997.

Ennis, R.H. (2011). The nature of critical thinking: an outline of critical thinking dispositions and abilities. University of Illinois. Retrieved from https://education.illinois.edu/

Forte, Jay. (2019). Curiosity and Critical Thinking. The Forte Factor

Pluck, Graham \& Johnson, H.. (2011). Stimulating curiosity to enhance learning. GESJ: $\quad$ Education Science and Psychology. 2 (19) pp. 24-31

Kashdan, Todd \& Steger, Michael \& Breen. (2007). Curiosity. Encyclopedia of Social Psychology, Chapter: Curiosity, (pp.81-94). Sage Publications.

Khairunisa, I.A. (2017). Peningkatan kemampuan bertanya dan penguasaan konsep peserta didik melalui penerapan question formulation technique pada materi virus dan bakteri. (Unpublished Master Thesis). Bandung: Universitas 
Pendidikan Indonesia.

Ko,H.Y. (2003). A study of the constructive of the quality management system for elementary and secondary school teacher in Taiwan. (Unpublished Master Thesis). Institute of Education of Nasional Sun Yat-Sen University, Taiwan.

Lindholm, M. (2018). Promoting curiosity? Sci \& Educ. 27 (1002). Doi.Org/10.1007/S11191-018-0015-7. Retrieved from https://link.springer.com/

Mitchell, Marilyn. P. (2015). Curiosity: the force within a hungry mind. Edutopia. George Lucas Educational Foundation.

Michael, Jody. (2018). 7 Benefits of intellectual curiosity (in case you were wondering) Jody Michael Associates. Retrieved from www.jodymichael.com

Olson, Eloise. (1986). Measurement of curiosity in junior high school students. (Retrospective Theses and Dissertations). Capstones: Lowa State University.

Rustaman, N., Dirdjosoemarto, S., Adi Yudianto S., Achmad Y., Subekti R, Rochintaniawati D, Nurjhani. (2005). Strategibelajar mengajar biologi. Malang: UM Press.

Schmitt F \& Lahroodi R. (2008). The epistemic value of curiosity. Educational Theory, 58 (2) pp.125-48. https://doi.org/10.1111/j.1741-5446.2008.00281.x

Tian, Huiseng. (2007). Educational wisdom and intellectual teacher are called on by the times. Front Education China. 2 pp.119-132

Von Stumm, S., Hell, B., Chamorro-Premuzic T. (2011) The hungry mind: intellectual curiosity is the third pillar of academic performance.Perspectives on Psychological Science. $6 \quad$ (6) pp. 574 DOI: $10.1177 / 1745691611421204$

Wright, S.P., Horn, S.P., \& Sanders, W.L. (1997). Teacher and classroom context effects on student achievement: implications for teacher evaluation. Journal of Personnel Evaluation in Education, 11 (1) pp. 57-67.

Widodo, P. (2012). Meningkatkan motivasi siswa bertanya melalui metode snowball throwing dalam pelajaran pendidikan keawarganegaraan. Jurnal Pendidikan Penabur. 13 (8) pp. 42- 55 